\title{
A NOTE ON THE SINGULARITY OF VALDÉS LEAL
}

\author{
UNA NOTA SOBRE LA SINGULARIDAD \\ DE VALDÉS LEAL
}

\author{
Peter Cherry \\ Trinity College Dublin. Ireland \\ pcherry@tcd.ie
}

\begin{abstract}
The present article considers the expression of the artistic individuality of Juan de Valdés Leal (1622-1690) in terms of his paint handling, with particular reference to his oil sketches and works in a small format. The problem of distinguishing the two categories of picture is discussed with relevant examples. Valdés Leal's innovative creation of a genre of small-format religious allegory is highlighted. His Jesuit connections led to a consideration of a projected ecclesiastical career for his son, Lucas Gregorio Valdés (1661-1725) and this is discussed in relation to the church careers of the sons of Murillo, José Murillo (1650-1679) and Gaspar Esteban Murillo (1661-1709). Finally, an examination of the early historiography of Valdés Leal's character and non-conformist style of painting raises the possibility that he deliberately set out to create an artistic persona as a unique genius.
\end{abstract}

Keywords: Valdés Leal; oil sketches; small-format paintings; artistic style; artistic personality.

El presente trabajo analiza la personalidad artística de Juan de Valdés Leal (1622-1690), atendiendo particularmente a su maestría como pintor al óleo, con especial énfasis en sus bocetos y obras de pequeño formato. La cuestión de la distinción entre dos clases de pintura -bocetos y obras de pequeño formato- se aborda mediante ejemplos significativos. El artículo pone de relieve la innovadora aportación por Valdés Leal del género de alegoría religiosa en pequeño formato. Sus vínculos con la Compañía de Jesús le llevaron a considerar la posibilidad de una carrera eclesiástica para su hijo, Lucas Gregorio Valdés (1661-1725), lo que se analiza en comparación con las carreras eclesiásticas de los hijos de Murillo, José Murillo (1650-1679) y Gaspar Esteban Murillo (1661-1709). Por último, un repaso a la historiografía temprana sobre el carácter de Valdés Leal y su inconformista estilo artístico avala la idea de que él mismo creara su papel como un genio diferente de todos los demás.

Palabras clave: Valdés Leal; bocetos; obras de pequeño formato; estilo artístico; personalidad artística.

Juan de Valdés Leal (1622-1690) cultivated an idiosyncratic artistic personality, which has long been celebrated. In one particular respect, however, his practice was conventional in the use of drawings and preparatory borrones, or oil 
sketches, for larger pictures. While Murillo's use of oil sketches has been the subject of scholarly inquiry, the same cannot be said for those of Valdés Leal ${ }^{1}$. Ideally, an investigation of the role of oil sketching in the production of paintings over his long career would take account of the larger context of the artist's working practices, including his drawings, but the latter have not yet received the sustained scholarly attention they deserve.

Fewer than ten borrones by Juan de Valdés Leal are known today ${ }^{2}$. It is significant that a number of them can be linked with altarpieces and cycles. Two may be related to the Jesuit cycle for the Casa Profesa in Seville. An image of San Fernando would appear to be a preparatory work for a large-scale painting commissioned from the chapter of the cathedral of Jaén in 1673, where the artist may have had to meet specific iconographic demands from the patrons. Oil sketches could have functioned as models in this way and have been made

1 The author is grateful to Aoife Brady, María Cruz de Carlos Varona, Pedro Martínez Plaza, José Roda Peña, and to those colleagues mentioned in the footnotes below, for their assistance with the preparation of this article. Art-historical interest in the work of Valdés Leal has lapsed of late; the last exhibition devoted to him was in 1991 at the Museo Nacional del Prado, organized by Enrique Valdivieso, who also compiled a catalogue of his works in his monograph on the artist of 1988. Perhaps the centenary of his birth in 2022 will provide a suitable opportunity for another serious look at the artist. For Murillo's oil sketches, see most recently CHERRY, Peter: "Murillo's oil sketches revisited", in conference proceedings, Congreso Internacional, Murillo ante su IV centenario. Perspectivas historiográficas y culturales, Seville 19-22 March, 2018.

2 The following paintings are accepted as oil sketches by the author and a number are discussed below. The Repulsion of the Saracens, measuring 35 × $24 \mathrm{~cm}$ (KINKEAD, Duncan: Juan de Valdés Leal (1622-1690). His Life and Work. New York, 1978, p. 334, nº 10, a sketch; VALDIVIESO, Enrique: Juan de Valdés Leal. Sevilla, 1988, p. 229, n 16), St. Ignacio Carried from the Battle of Pamplona, and the Apparition of San Pedro to San Ignacio at Pamplona, measuring 44 x $35 \mathrm{~cm}$ (KINKEAD, Duncan: Juan de Valdés Leal..., op. cit., pp. 435-36, $\mathrm{n}^{\circ} 117$, a sketch; p. 437, n 118 s, a sketch; VALDIVIESO, Enrique: Valdés Leal..., op. cit., p. 245, $\mathrm{n}^{\circ} 83$ y 84) are in unknown locations. The Immaculate Conception (39 x $25 \mathrm{cms}$ ), in a private collection (KINKEAD, Duncan: Juan de Valdés Leal..., op. cit., p. 419, $\mathrm{n}^{\circ}$ 99s, a sketch; VALDIVIESO, Enrique: Valdés Leal..., op. cit., p. 256, n ${ }^{\circ} 149$ ) and the Assumption of the Virgin (39 x $25 \mathrm{cms})$ in the Cleveland Museum of Art (KINKEAD, Duncan: Juan de Valdés Leal..., op. cit., p. 420, n 100s, a sketch; VALDIVIESO, Enrique: Valdés Leal..., op. cit., p. 255, $\mathrm{n}^{\circ}$. 147) are, unusually, painted on panel. A Mystic Marriage of St. Catherine $(45 \times 31 \mathrm{~cm})$ is in the Musée Ernest Rupin, Brive la Gaillarde (KINKEAD, Duncan: Valdés Leal..., op. cit., p. 465, $\mathrm{n}^{\circ}$ 144, a sketch; VALDIVIESO, Enrique: Valdés Leal..., op. cit., p. 266, $\mathrm{n}^{\circ}$ 198) and a painting of The Virgin Giving the Chasuble to St. Ildefonso $(60 \times 81 \mathrm{cms})$ in the Museo Nacional de Cataluña (KINKEAD, Duncan: Juan de Valdés Leal..., op. cit., p. 409, nº 85c, a sketch; VALDIVIESO, Enrique: Valdés Leal..., op. cit., p. 250, $\left.\mathrm{n}^{\circ} 113\right)$. A San Fernando $(56 \times 37 \mathrm{cms})$ is in a private collection in Madrid (VALDIVIESO, Enrique: Valdés Leal..., op. cit., p. 259, nº 161). 
to be submitted for the approval of clients, although this function, if it existed, is not explicitly mentioned in documented contracts for Valdés Leal. It is likely, however, that most oil sketches were made autonomously on an ad hoc basis by the artist in order to study compositions in colour ahead of the large-scale final picture.

Two small-scale pictures have been considered preparatory oil sketches for the Immaculate Conception and the Assumption of the Virgin (both Museo de Bellas Artes, Seville), which Valdés Leal painted c. 1670-72 for side altars of the church of the convent of San Agustín in Seville. The Immaculate Conception in a private collection $(39 \times 25 \mathrm{~cm})$ is related to the larger work in terms of the poses of the Virgin and number of the cherubs, and the witty motif of the cherub repelling the snake of Original Sin with an olive branch is used in both ${ }^{3}$. However, the Virgin is evidently younger in the small painting and the composition is much simplified vis-à-vis the other, with far fewer angels. It could have been a first idea, but it could equally have been made after the large picture, perhaps as a scaled-down small version for sale. Perhaps the commission concentrated Valdés Leal's mind on the theme in hand and this in turn generated a number of versions of it in different formats. In this regard, it is worth noting that, despite the free handling of the paint, all of the details of the iconography are explicitly stated. The pendant Assumption of the Virgin (40,3 x $26,6 \mathrm{~cm}$ ) in the Cleveland Museum of Art is close to its larger counterpart, although the figures are larger in the pictorial field in the latter and have less ambient space around them ${ }^{4}$. It too is sketchily painted -even more freely handled than the small Immaculate Conception- but the details of its iconography are also clear. Both works are on panel, an unusual support for oil sketches, and they are painted in a conventional rectangular format, which does not take account of the arched sections of large works -although in the Immaculate Conception two arched areas of clouds appear at the bottom corners of the work-. While a relationship with the finished altarpieces for San Agustín is undeniable, these small works raise the problem of distinguishing Valdés Leal's borrones from his small pictures.

This kind of confusion bedevils the study of Valdés Leal's painting. The visual differences between his oil sketches and his small paintings are less marked

${ }^{3}$ KINKEAD, Duncan: Juan de Valdés Leal..., op. cit., p. 419, n ${ }^{\circ} 99 \mathrm{~s}$; and VALDIVIESO, Enrique: Valdés Leal..., op. cit., p. 256, nº 149.

${ }^{4}$ KINKEAD, Duncan: Juan de Valdés Leal..., op. cit., p. 420, n ${ }^{\circ} 100 \mathrm{~s}$; and VALDIVIESO, Enrique: Valdés Leal..., op. cit., p. 255, no 147.

${ }^{5}$ KINKEAD, Duncan: Juan de Valdés Leal..., op. cit., identified pictures which he believed to be oil sketches and related them to paintings, although he did not discuss their function. He accepted the existence of small-format paintings, although did not develop this point. VALDIVIESO, Enrique: Valdés Leal..., op. cit., is generally reluctant to 
than in the case of Murillo, due to the artist's generalized use of a sketchy facture made up of independent brush-strokes. An instructive technical contrast can be made between his oil sketch of the Mystic Marriage of St. Catherine $(45 \times 31 \mathrm{~cm})$ in the Musée Ernest Rupin (Brive la Gaillarde) and Murillo's oil sketch of the same subject $(71,1 \times 52,07 \mathrm{~cm})$ in the Los Angeles County Museum of Art ${ }^{6}$. Murillo's work is characterized by its fluid, integrated brushwork, transparent colours, even lighting, and lucid forms. Valdés Leal's image, on the other hand, is made up of spontaneous, separate touches of the brush, flashing highlights, and dramatic contrasts of light and dark in a field of an overall dark tonality. Indeed, this dynamic style characterizes his works in all sizes. In large-scale pictures, the vibrant illumination and the bold brushwork ensured that his paintings for altarpieces, for instance, registered with force and clarity from a distance and in less than optimum light conditions. Its functional rationale aside, however, it is this signature style which set him apart from his peers in Seville.

Collectors in the nineteenth century evidently experienced less difficulty in recognizing oil sketches by Valdés Leal and Murillo. Doubtless their expectations around the old masters were coloured by the fact that oil sketching was an established part of artistic practice by this time. The collection of Aniceto Bravo in Seville in 1842, for instance, included sixteen paintings attributed to Valdés Leal, of which six were said to be sketches, and thirty one paintings given to Murillo, of which seven were recorded as sketches ${ }^{7}$. Like Murillo, Valdés probably did not market his borrones in his lifetime and these remained studio properties, belonging to the artist. Only one, a Massacre of the Innocents, has been documented in a collection in Seville in his lifetime, owned by Carlos de Licht in $1689^{8}$. Judging from its subject matter, this is likely to have been a dynamic

accept the existence of small-scale paintings, characterizing most of this type as preparatory works for larger images.

${ }^{6}$ KINKEAD, Duncan: Juan de Valdés Leal..., op. cit., p. 465, ${ }^{\circ} 144$; and VALDIVIESO, Enrique: Valdés Leal..., op. cit., p. 266, n 197 . This sketch generated three large-scale versions of the composition, only one of which (Museo de Bellas Artes, Seville) appears to be by Valdés Leal himself. Ibidem, p. 266, n 198, 199 y 200.

7 CÓMEZ RAMOS, Rafael: "Coleccionistas de pintura en Sevilla en 1842", Laboratorio de Arte, 5, 1993, pp. 159-165, esp. p. 162. There were also bocetos given to Alonso Cano, Francisco de Herrera el Viejo, Sebastián Llanos y Valdés, and Francisco Antolínez y Sarabia.

${ }^{8}$ QUILES GARCÍA, Fernando: "Cornelio Schut el Mozo, un retratista en la Sevilla del barroco", Goya, 325, 2008, pp. 299-311, esp. p. 307, for the "país borron de Valdes de Herodes y los Ynnocentes de una vara de largo y tres cuartas de alto...". Measuring $63 \mathrm{x}$ $84 \mathrm{~cm}$, this was larger than the norm for such works, although consistent with some of the artist's sketchily painted smaller scale pictures. It is unclear whether the measurements included the frame. 
composition of many figures. An oil sketch measuring 35 x 24,5 cm made in preparation for the Repulsion of the Saracens from Assisi in Seville's Ayuntamiento, now known only in a photograph, might be imagined to be an equivalent kind of work ${ }^{9}$. Here, the tumultuous action is expressed in lively painterly shorthand, with forms articulated with broad touches of the paint-laden brush and bold modelling with lead white. There are significant differences between the oil sketch and the final work; most noticeably in the latter, Valdés Leal has opted for a theatrical intensification of engagement with the subject in three figures whose gaze meets that of the viewer and who wear exaggerated expressions of fear. The example demonstrates that the oil sketch did not serve as a model, but marked a point of resolution on a creative continuum, which was subject to revision.

A systematic survey of collection inventories in seventeenth-century Seville would probably reveal a greater number of small paintings by his hand. Who, for instance, was the original owner of the exquisite small painting in a horizontal format of the Assumption of the Virgin $(36 \times 54 \mathrm{~cm})$ in the Museo de Bellas Artes in Seville? ${ }^{10}$ One documented work of this kind is the vertical-format small painting of the Assumption of the Virgin $(50 \times 33,5 \mathrm{~cm})$, which was acquired in Madrid in 1676 by the imperial ambassador Ferdinand Bonaventure Harrach, and remains in the family collection at Schloss Rohrau ${ }^{11}$. Perhaps Valdés Leal painted these works at the same time, in a period of sustained creative concentration on this particular theme. Such a phenomenon was certainly in keeping with the practices of drawing. It is unknown whether Harrach bought the $A s$ sumption on the Madrid art market or from the artist, and whether he saw it as a borrón or as a finished small picture. It is worth noting that its style and touch is close to the above-mentioned small-format Immaculate Conception. The oil sketch was a conventional form of preparation in Madrid. Oil sketches were habitual in the practices of Juan Carreño and Claudio Coello, among others. In this respect, the role of Francisco de Herrera the Younger, who worked in both Seville and Madrid, was probably crucial. The oil sketch may even have been a collectible in the context of an art market, which was many times greater than that of Seville. If Harrach did, therefore, acquire his painting as a sketch, he

${ }^{9}$ KINKEAD, Duncan: Juan de Valdés Leal..., op. cit., p. 334, $\mathrm{n}^{\circ} 10$; and VALDIVIESO, Enrique: Valdés Leal..., op. cit., p. 229, nº 16.

${ }^{10}$ VALDIVIESO, Enrique: Valdés Leal..., op. cit., p. 266, n 195, as probably "un modelo para una composición de mayores proporciones".

${ }^{11}$ KINKEAD, Duncan: Juan de Valdés Leal..., op. cit., p. 422, cat. 101s; and VALDIVIESO, Enrique: Valdés Leal..., op. cit., p. 252, n 121. Both authors consider the work an oil sketch for the large-scale painting of this subject now in the National Gallery of Art, Washington. The diary of Count Ferdinand Bonaventure Harrach recording its purchase on 27 September, 1676 gave only its subject matter and price (six doblones). 
would have joined the ranks of a particular type of connoisseur who appreciated this kind of painterly handling.

Valdés Leal was evidently aware of his "gran magisterio y bizarría" early on in his career ${ }^{12}$. He appears to have created a taste and a clientele for small-format pictures painted in a particularly sketchy manner, as can be seen in the paintings of the Marriage at Cana and the Feast in the House of Simon in the Musée du Louvre (both 24 x $34 \mathrm{~cm}$ ), signed and dated $1660^{13}$. In these, he adopted the Flemish technique of oil paint on panel, where the non-absorbent support allowed the full immediacy and range of his touch to be expressed with force and eloquence $^{14}$. It was likely to be this virtuosity which was so admired by their original owners. Another case in point is the small painting of The Exaltation of the Cross in the J. Paul Getty Museum, Los Angeles (60 x $105 \mathrm{~cm})$, which has been considered variously an oil sketch and a model in preparation for Valdés Leal's fresco of this subject in the choir of the church of the hospital of the Caridad (Figura 1) ${ }^{15}$. The significant difference between the two compositions, however, suggests that the smaller piece can be more accurately regarded as an independent work -a version of the subject made for a market among private collectors and painted freely with a marked use of wet-in-wet brushwork-. Indeed, a significant number of examples of small-format paintings are known which exhibit Valdés Leal's spirited paint handling and which evidently appealed to collectors for this reason; these include The Virgin and Child with

12 The phrase is Palomino's, speaking of his early works for the high altar of the church of the Carmen Calzado in Córdoba, "hechas con gran magisterio y bizarría". PALOMINO, Antonio: Vidas. Madrid, 1986, p. 311.

13 VALDIVIESO, Enrique: Valdés Leal..., op. cit., pp. 121-124; p. 244, n 81 y 82; and GERARD POWELL, Véronique and RESSORT, Claudie: Musée du Louvre. Département des Peintures. Catalogue Écoles espagnole et portugaise. Paris, 2002, pp. 244-247. Another painting of this kind is the signed small St. Thomas of Villanueva Giving Alms, also painted on panel $(28 \times 43 \mathrm{~cm})$ in the El Paso Museum of Art. KINKEAD, Duncan: Juan de Valdés Leal..., op. cit., pp. 458-59, n ${ }^{\circ} 141$; and VALDIVIESO, Enrique: Valdés Leal..., op. cit., p. $266, n^{\circ} 196$. These authors suggest the last functioned as a predella panel.

14 Valdés Leal appears to have been aware of the popularity of Flemish supports on the Spanish market. His earliest known contract, dated 7 June 1647, is for painting twelve coppers (measuring some $63,5 \times 60 \mathrm{~cm}$ ) of subjects of the patron Francisco de Torquemada's choosing. See VALVERDE MADRID, José: "Dos pintores sevillanos en Córdoba: Sarabia y Valdés Leal", Archivo Hispalense, 39, 120-121, 1963, pp. 14 y 54; and KINKEAD, Duncan: Juan de Valdés Leal..., op. cit., pp. 4 y 528.

${ }^{15}$ KINKEAD, Duncan: Juan de Valdés Leal..., op. cit., pp. 454-55, n $137 \mathrm{~s}$; and VALDIVIESO, Enrique: Valdés Leal..., op. cit., p. 278. Neither author, however, had seen the work at the time of compiling their catalogues. For a reduced variant of the Caridad fresco in a small format $(60 \times 105 \mathrm{~cm})$ by Lucas Valdés, see FERNÁNDEZ LÓPEZ, José: Lucas Valdés (1661-1725). Seville, 2003, p. 87, nº 1. 
SS. Isidoro, Leandro, Hermenegildo and Recaredo $(34 \times 42 \mathrm{~cm})$ in a private collection, The Virgin Giving the Chasuble to S. Ildefonso $(60,5 \times 81 \mathrm{~cm})$ in the $\mathrm{Mu}$ seo Nacional d'Art de Catalunya (Figura 2), St. Fernando Discovering the Image of the Virgin of a Antigua $(45,3 \times 35,7 \mathrm{~cm})$ in a private collection, and the Vision of St. Rosa de Lima (panel $25 \times 20 \mathrm{~cm})^{16}$.

The small format appears to have been exploited by Valdés Leal for allegorical subjects. One, representing The Christ Child Embracing the Cross with St. John the Baptist (36 x $24 \mathrm{~cm})$, is signed and dated $1659^{17}$. Another example is the Allegory of the Immaculate Conception in the Courtauld Institute Galleries $(55 \times 51 \mathrm{~cm})^{18}$. This shows the Virgin Immaculate as a young girl with her heart pierced by a ray of light from the wound in the side of the crucified Christ, overseen by God the Father and accompanied by angels, while light pours into a chalice below on the threshold of a doorway, the porta coeli. In the lower part of the picture, on the right, Franciscans witness this event and, inspired by the dove of the Holy Spirit, record it in books, while, on the left, two popes (perhaps Gregory XV and Alexander VII) hold documents -doubtless representing papal bulls-and a putto points to one of these in the foreground. It is likely that the painting responds to Alexander VII's bull Sollicitudo omnium ecclesiarum of 8 December 1661, in which the papacy endorsed the feast of the Immaculate Conception and decreed in favour of the belief that her soul was preserved from original sin from the first instant of its creation and infusion into her body. In formal terms, this work is a response to the Allegory of the Holy Sacrament by Francisco de Herrera el Mozo, painted in 1656 for the Hermandad Sacramental del Sagrario of Seville Cathedral, in the same year as Valdés Leal took up residence in the city ${ }^{19}$. However, its original and recondite iconography seems to be

16 This is only to mention works which the author has examined first-hand. For the first, see KINKEAD, Duncan: Juan de Valdés Leal..., op. cit., pp. 469-70, ${ }^{\circ} 148$; and VALDIVIESO, Enrique: Valdés Leal..., op. cit., p. 265, $\mathrm{n}^{\circ} 193$. The last was offered at Subastas Alcalá, Madrid, Pintura Antigua, 15-16 March, 2017, n $^{\circ} 207$. For others, see VALDIVIESO, Enrique: Valdés Leal..., op. cit., p. 249, $\mathrm{n}^{\circ} 105$, Christ on the Way to Calvary (89 x 71 cm), Bilbao, Museo de Bellas Artes; p. 253, $\mathrm{n}^{\circ}$ 129, The Death of St. Peter Martyr (?), dimensions unknown, location unknown; p. 265, $\mathrm{n}^{\circ}$ 192, The Birth of the Virgin (50,5 $\mathrm{x}$ 64,5 cm), Museo Nacional de Bellas Artes, Buenos Aires.

${ }^{17}$ KINKEAD, Duncan: Juan de Valdés Leal..., op. cit., p. 414, cat. 93; and VALDIVIESO, Enrique: Valdés Leal..., op. cit., p. 248, nº 102.

${ }^{18}$ KINKEAD, Duncan: Juan de Valdés Leal..., op. cit., pp. 417-18, n 98; and VALDIVIESO, Enrique: Valdés Leal..., op. cit., p. 252, n 123 . The author is grateful to Kate Edmondson, Chloe Le Tissier, Nicole Ryder, and Karren Serres for facilitating first-hand examination of the picture.

19 A small-scale version of Herrera's picture -described as an oil sketch- may also have helped shape Valdés Leal's concept of the small picture. ILLÁN MARTÍN, Magdalena: "La colección pictórica del Conde de Águila", Laboratorio de Arte, 13, 2000, pp. 
the artist's own invention, and would have been appreciated by a relatively specialized audience with eyes capable of reading it.

Valdés Leal's inventive mind was evidently suited to the creation of images of relatively complex iconography, which are close to the world of the -obviously small-scale- religious print. In this respect, his pair of Vanitas subjects in York and Hartford -in which books are a dominant motif- is eloquent. It is significant that he found favour with the Jesuit order ${ }^{20}$. In 1661, Valdés Leal was commissioned to paint the series of the life of St. Ignatius Loyola for the Casa Profesa of Seville and the centerpiece of one of the pictures -representing SS. Ignatius and Francisco de Borja- is the allegorical image of the Eucharistic Christ Child standing on a metal flaming "candelabrum" of His name, along with the Virgin and God the Father (Seville, Museo de Bellas Artes). Valdes Leal's son, Lucas Gregorio Valdés (1661-1725), was also given to these kinds of works ${ }^{21}$. The sources speak of his father's desire for his son's intellectual formation beyond the workshop and he may well have availed of his connections with the Jesuit order to place him in the Seville College of San Hermenegildo el

123-51, esp. pp. 133, 146 for "Otro Quadro un Borroncito Alegorico del misterio del Ssmo. Sacramento, de sus principios de d[ic]ho Auttor Herrera el Moso" in the collection of the Conde del Águila. The "boceto" in the collection of deán Manuel López Cepero (17781858) appears too large to be the same work in the former collection. It is listed in his postmortem inventory as: " 884 . L. Boceto del cuadro pintado $\mathrm{p}^{\mathrm{r} .}$ Herrera el mozo p. ${ }^{\mathrm{a}}$ la testera de la Sala de la Hermandad del $\mathrm{S}^{\mathrm{mo}}$. del Sagrario" and measured 1 vara 22 pies high x 2 varas 15 pies long. It is mentioned in José Amador de los Ríos, Sevilla pintoresca in 1844 (p. 455), although its size is not given. The author is grateful to Pedro J. Martínez Plaza for this information. See also MERCHÁN CANTISÁN, Regla: El deán López Cepero y su colección pictórica. Seville, 1979, p. 83; and CÓMEZ RAMOS, Rafael: "Coleccionistas...", op. cit., p. 160. For a large version of this picture in the Seville church of Santa María la Blanca, see FALCÓN MÁRQUEZ, Teodoro: La iglesia de Santa María la Blanca y su entorno. Sevilla, 2015, p. 124.

${ }^{20}$ RODRÍGUEZ G. DE CEBALLOS, Alfonso: "El pintor Valdés Leal y la Compañía", Archivum Historicum Societatis Iesu, 35, 1966, pp. 242-249.

${ }^{21}$ See, for instance, FERNÁNDEZ LÓPEZ, José: Lucas Valdés..., op. cit., p. 101, no 48 (lám. 9), for a Eucharistic Allegory $(128 \times 108 \mathrm{~cm})$ in the Parroquia de San Pedro, Sevilla; Ibidem, p. 104, nº 55 (lám. 11) for a large-scale Triumph of the Eucharist in the Parroquia de San Isidoro; Ibid., pp. 76-81 (lám. 12) for his fresco of the Triumph of the Faith in the Parroquia de la Magdalena. It is worth noting in this context that Lucas provided eighteen etchings of emblems for Fernando de la Torre Farfán's Fiestas de S. Iglesia Metropolitana y Patriarcal de Sevilla al Nuevo culto del Señor Rey S. Fernando el tercero de Castilla y de León (1672), in one set signing with his age of eleven years old, alongside others signed by his sister Luisa de Morales. 
Mártir, where he could have been trained in the mathematical skills necessary for his future career as a fresco painter ${ }^{22}$.

It may be noted here that Lucas, in fact, celebrated his first tonsure "de corona" at the age of sixteen before Archbishop Spínola in the oratory of the Palacio Arzobispal ${ }^{23}$. There is no record of his proceeding further in holy orders and he married in November $1682^{24}$. Lucas Valdés may or may not have had a religious vocation. This apart, his parents were evidently prepared to invest in this career for their son for the social prestige, which this conferred on the family. It is currently unclear how many artists' sons might have taken this path in life, or, for that matter, how many of their daughters took the veil ${ }^{25}$. To the knowledge of the present writer a systematic survey of the existing documentation has not been undertaken with this in mind. One who may be added to the list was Esteban de Iriarte, the son of the landscape painter Ignacio de Iriarte $^{26}$. It has long been known that two of Murillo's sons were ordained. José Murillo (1650-1679) is recorded receiving the tonsure in October 1677, soon after Lucas Valdés, and ordained "de Epístola" two years later, attaining the

${ }^{22}$ CEÁN BERMÚDEZ, Juan Agustín: Diccionario histórico de los más ilustres profesores de las Bellas Artes en España. T. V. Madrid, 1800, p. 104: "Manifestó su inclinación á la pintura desde su infancia; pero su padre ántes de enseñársela quiso que aprendiera la latinidad y las matemáticas con los jesuitas"; FERNÁNDEZ LÓPEZ, José: Lucas Valdés..., op. cit., p. 16; and FUENTES LÁZARO, Sara: "La práctica de la cuadratura en España: el caso de Lucas Valdés (1661-1725)", Anales de Historia del Arte, 19, 2009, pp. 195-210, esp. pp. 206-210.

23 AGAS (Archivo General del Arzobispado de Sevilla), leg. 05355, Libro de registro de órdenes 6 (1670-80), f. 140v, "Sev[ill]a Corona/ En quatro del d[ic]ho [julio de 1677] ordenó el Ar[zo]b[is]po mi s[eñ]or en su Orat[o]rio de Corona a D. Lucas de Valdes h[ijo] 1[egítimo] de Juan de Valdes y de $\mathrm{D}^{\mathrm{a}}$ Isabel de Carrasquilla su mug[e]r vez[in]os de Sevilla". The register does not note where the ordinand studied. The oratory for these ceremonies is not to be confused with the private "oratorio bajo" of the archbishop for which Murillo's Virgin and Child and Valdés Leal's series of the Life of San Ambrosio were commissioned in 1673. See ÁLVAREZ LÓPERA, José: Valdés Leal. La vida de San Ambrosio. Madrid, 2003.

${ }^{24}$ FERNÁNDEZ LÓPEZ, José: Lucas Valdés..., op. cit., p. 32.

${ }_{25}$ Murillo's daughter, Francisca María, professed in the convent of Madre de Dios and Valdés Leal's daughter, María de la Concepción, professed in the convent of San Clemente el Real. See, respectively, ANGULO ÍÑIGUEZ, Diego: Murillo. Su vida, su arte, su obra. Madrid, 1981, I, p. 128; and GESTOSO Y PÉREZ, José: Biografía del pintor sevillano Juan de Valdés Leal. Sevilla, 1916, p. 143.

${ }^{26}$ AGAS, leg. 05356, Libro de registro de órdenes 8 (1680-1689), f. 36, "Junio año de 1681/ Corona Sevilla/ Su Ill[ustrísi]ma en su oratorio ordenó de corona a Estevan de Iriarte, colleg[ia]l de san ysidro h[ijo] 1[egítimo] de Ignacio de Iriarte y $\mathrm{D}^{\mathrm{a}}$ Maria de Escovar vecinos de Sevilla". 
rank of sub-deacon ${ }^{27}$. His brother Gaspar Esteban Murillo (1661-1709) enjoyed the most successful ecclesiastical career, going on to become a canon of Seville cathedral $^{28}$. This particular advancement involved considerable expense and the protection of influential supporters, the most important of whom was José de Veitia, Secretario del Despacho Universal ${ }^{29}$.

${ }^{27}$ See ANGULO ÍÑIGUEZ, Diego: Murillo..., op. cit., I, p. 128. José Murillo received his first tonsure on 22 October, 1677. See AGAS, leg. 05355, Libro de registro de órdenes 6 (1670-80), f. 146, "Sev[ill]a Corona y grados/ En veynte y siete [de octubre de 1677] dio cedula para que el s[eñ]or ob[is]po ordenare de corona y Grados a $\mathrm{D}^{\mathrm{n}}$ Joseph Murillo $\mathrm{H}\left[\mathrm{ijo}\right.$ ] 1[egítimo] de D B[artolo]me Murillo y D ${ }^{\mathrm{a}}$ Beatriz de Sotomayor su Muger vecinos de Sevilla". He was ordained "de Epístola" in the parish of San Isidro in April 1679. See AGAS, leg. 05355, Libro de registro de órdenes 6 (1670-80), "Abril [1679]/ Epistola seculares", f. 171; Libro de registro de órdenes 7 (1671-1679), año 1679. See HEREZA, Pablo: Corpus Murillo. Biografía y documentos. Sevilla, 2017, docs. 220, 247 for the chaplaincy José administered in Pilas and which was taken over by his brother, Gaspar Esteban, after his death.

${ }^{28}$ See ANGULO IÑIGUEZ, Diego: Murillo..., op. cit., I, pp. 132-35. Gaspar received his first tonsure in 1675. See AGAS, leg. 05355, Libro de registro de órdenes 6 (16701680), f. 89, "Corona Sevilla/ Diose cedula para q el s[eñ]or obispo [de Viserta] ordensasse de corona a $\mathrm{D}^{\mathrm{n}}$ Gaspar Estevan Murillo Hijo L[egítim]o de $\mathrm{D}^{\mathrm{n}} \mathrm{B}$ [artolo]me Murillo y $\mathrm{D}^{\mathrm{a}}$ Beatriz de Cabrera su Muger vecinos de Sevilla en d[ic]ho dia [16 de marzo de 1675]". Ibidem, f. 134, for his ordination "de grados" in 1677, "Grados Sev[ill]a/ En veynte del d[ic] ho [abril de 1677] ordenó su Ill[ustrísi]ma de Gradis disp. int, a D. Gaspar Murillo tonsurado de Sevilla". See HEREZA, Pablo: Corpus Murillo..., op. cit., docs. 199, 206 for notification of his ordination posted in the parish church of San Bartolomé in 1675 and 1677. In 1685 , he is recorded among those ordained "de Epístola" in the saloon ("salon") of the Archbishop's palace. See AGAS, leg. 05356, Libro de registro de órdenes 8 (1680-1689), f. 107, 22 December 1685, “... D Gaspar Estevan Murillo canónigo de la S[an]ta Igl[esi]a a tit[ul]o de su prebenda ....". He had presented his "limpieza de sangre" to become a canon of Seville cathedral in September 1685. See DE SALAZAR MIR, Adolfo: Los expedientes de limpieza de sangre de la Catedral de Sevilla. Madrid, 1995; and HEREZA, Pablo: Corpus Murillo..., op. cit. p. 51, n. 70. He took possession of his office on 1 October, 1685. See AGAS, sección I, Secretaría, lib. 381, Libro de entradas de los S[eño]res Prebendados, f. 50. Gaspar Esteban was chaplain of the chapel of Nuestra Señora de la Concepción of Seville cathedral. He became a member of the Brotherhood of Charity on 18 November, 1685. See ASC (Archivo de la Santa Caridad), Libro donde se asientan los hermanos de la Cofradia de la Santa Caridad. In 1703, he was given permission to celebrate mass in the oratory of a rural property of his (AGAS, Gobierno, Oratorios Privados, leg. 4, doc. 51-A, 8 March, 1695) and his own houses in Seville (Ibidem, leg. 4, doc. 50, 22 October, 1703). He died in the plague in Seville in 1709.

${ }^{29}$ On 17 January, 1685, king Charles II wrote a dispatch to his agent in Rome, don Francisco Bernardo de Quirós, to negotiate with the Holy See regarding the award of the Arcedianato de Jérez, vacated by the death of don Rodrigo de Quintanilla, and a canonry of Seville cathedral to Gaspar Esteban Murillo, described as "sobrino de d" Joseph 
Antonio Palomino gave an eye-witness account of Valdés Leal working. He described the artist painting a set of large-scale female virgin saints for the lawyer Tomás del Castillo "y de ordinario era en pie, porque gustaba de retirarse de cuando en cuando, y volver prontamente a dar algunos golpes, y vuelta a retirarse; y de esta suerte era de ordinario su modo de pintar, con aquella inquietud, y viveza de su natural genio" ${ }^{30}$. Palomino felt this experience worthy of record because the artist's physically dynamic method -stepping back from the canvas in order to judge the expressive value of his brushstrokes in relation to the whole image from a certain distance- demonstrated a restless and lively creative mind. The text assumes that Valdés Leal's temperament and creativity are connected "naturally", and, therefore, that his highly personal style communicated the artist's unique artistic identity ${ }^{31}$.

Valdés Leal's etched self-portrait (Biblioteca Nacional, Madrid) is contained within an elaborate anthropomorphic cartouche, which would seem to symbolize the very fantasia of the artist, with a laurel-crowned cherub above and room for an inscription on a banderole. The artist looks askance with what might be regarded as a disdainful, mistrusting expression, although any such interpretation risks being coloured by Palomino's account of his personality. Palomino, who knew Valdés Leal personally, represents a complex individual who is characterized by his arrogant temperament ("genio altivo"). He speaks of an estrangement between him and Murillo in the Seville drawing academy, saying that while Valdés Leal was president Murillo organized alternative drawing sessions in his

de Veitia mi secret. ${ }^{\text {ro }}$ de estado, y del Despacho Univ. ${ }^{1}$...”. The dispatch also bore the signature of Joseph de Veitia. See AMAE (Archivo del Ministerio de Asuntos Exteriores), Madrid, Santa Sede, leg. 76, ff. 134-136. In another dispatch of 19 April, 1685, the King authorized Quirós to express his gratitude to the Holy See for the concession of one of the offices on Gaspar Esteban, the canonry of Seville cathedral. This dispatch also bears the signature of Veitia. AMAE, Madrid, Santa Sede, leg. 76, f. 177a. PALOMINO, Antonio: Vidas..., op. cit., p. 294 notes the social prestige enjoyed by Murillo via his sons' ecclesiastical careers and the role of Veitia in securing them their benefices. Veitia was the husband of Tomasa Murillo, daughter of the painter's sister, Ana. See DE SOLANO, F.: Norte sobre la vida y obra del autor del "Norte de la Contratación de las Indias Occidentales". Madrid, 1982. See also CEÁN BERMÚDEZ, Juan Agustín: Diccionario..., op. cit., II, pp. 65-66, s. v. "Esteban Murillo (D. Gaspar)".

${ }_{30}$ PALOMINO, Antonio: Vidas..., op. cit., p. 312.

${ }^{31}$ KRIS, Ernst and KURZ, Otto: Legend, Myth, and Magic in the Image of the Artist. New Haven and London, 1979, pp. 119, 126 for the topos of the artist "in" his work. CEÁN BERMÚDEZ, Juan Agustín: Diccionario..., op. cit., V, p. 107, noted that, from the beginning, Valdés' style was his own: "con su viveza extraordinaria tomó otro rumbo diferente del estilo de [Antonio] de Castillo, pintando más abreviado". 
house "por no tropezarse con lo altivo de su natural" 32 . He quoted Murillo's observation that "Valdés en todo quería ser solo" and concluded that "no podía su genio sufrir, no digo superior, pero ni igual en cosa alguna". He illustrates this trait with the case of a roguish ("tunante") Italian painter, whose novel drawing technique in the Seville academy aroused Valdés' jealousy ${ }^{33}$. After Valdés expelled the Italian from the academy, the latter painted two nudes, a Crucifixion and a St. Sebastian "pintados con valentía" in an unusual technique, which he exhibited to public acclaim on the steps of the cathedral ${ }^{34}$. This enraged Valdés to the point that he wanted to kill him and forced him to leave town. Palomino said that many criticized Valdés' behavior and especially Murillo "pues dijo, que la soberanía de Valdés era tanta, que no admitía competencia. A tanto como esto llegaba la altivez de su genio". In light of this, Valdés' justification, given in Palomino, that he was defending the reputation of the academy against the mockery of the foreigner, does not ring true. The key to Valdés' jealous rage may lie in the technical novelty of the Italian's improvised and spontaneous way of drawing and painting, because he had reserved the role of extravagante for himself. Indeed, Palomino says that Valdés even imitated the success of the Italian when he drew in the artists' academies in Madrid in 1664, "y que dibujaba dos, o tres figuras cada noche (debiera de seguir la pauta de aquel viandante), galantería, que muchos la han ejecutado por bizarrear".

Ceán Bermúdez stressed the antagonism between Murillo and Valdés Leal in the Seville drawing academy, and attributed this to the character of the latter $^{35}$. He exemplified their difference in personality via Valdés Leal's hieroglyphs in the church of the hospital of the Caridad, In Ictu Oculi and Finis

${ }^{32}$ PALOMINO, Antonio: Vidas..., op. cit., p. 312.

33 Ibidem. The Italian was praised by colleagues for drawing three figures per evening in the Seville drawing academy in a novel graphic technique, "un modo de dibuxar tan nuevo y al parecer tan fácil" (drawing the figure out of the charcoal-covered paper with a piece of bread). Valdés Leal "no pudo sufrir los elogios que hacían al forestero, y no le dexó dibuxar mas que quatro noches". CÉAN BERMÚDEZ, Juan Agustín: Diccionario... T. V, op. cit., p. 109.

${ }^{34}$ Palomino describes the figures on the primed canvases as a kind of coloured drawing, "todo plumeado con los colores, cosa excelente, y por tan extraño camino, que casó admiración...". PALOMINO, Antonio: Vidas..., op. cit., p. 312.

${ }_{35}$ CEÁN BERMÚDEZ, Juan Agustín: Diccionario..., op. cit., II, pp. 55-56; V, p. 108. Ceán Bermúdez knew the manuscript of the Seville drawing academy and interpreted its data in accordance with the received character of Valdés. He noted that Valdés was elected mayordomo of the academy in 1663, "pero se desistió en 11 de febrero por varias disputas originadas por su genio dominante". He was made president in November 1663 until 1666, "en que hizo desestimiento formal y por escrito, también por su carácter orgulloso". At this time occurred "aquel pasage del pintor tunante que cuenta Palomino". In fact, the biography of Ceán is more moralistic than Palomino's. 
Gloriae Mundi: "El prudente Murillo tuvo que sufrir la dureza de su genio y la envidia de que estaba poseido, pues celebrando con blandura y oportunidad las obras que pintaba Valdes, cortaba con choques que cada dia habia entre los dos. Así lo hizo quando colocados los dos quadros que D. Juan pintó para debaxo del coro de la Caridad, que representa uno de ellos varios cuerpos muertos y casi corrompidos, le dixo Bartolomé: «Compadre, esto es preciso verlo con las manos en las narices». Elogio que tranquilizó á Valdes de los que todo el mundo hacia á los demas lienzos que hay de Murillo en la misma iglesia". ${ }^{36}$ This anecdote is probably extrapolated from the description of these paintings by Palomino, in which the depiction of dead bodies and corruption is regarded as so realistic as to cause somatic effects in viewers, who feared contagion by miasma ${ }^{37}$. It is worth noting that the respective paintings of the artists in the church of the hospital of the Caridad went on to play a central role in the construction of their opposing personalities in subsequent historiography ${ }^{38}$. The perceived virtuous character of Murillo -modest, discreet, unassuming, honest, affable, generous, charitable and, of course, pious- functioned all the better by force of contrast with that of Valdés Leal ${ }^{39}$. However, Valdés Leal's superiority can also be seen in terms of a self-fashioning strategy in a competitive

${ }^{36}$ Ibidem, V, pp. 111-112.

${ }^{37}$ PALOMINO, Antonio: Vidas..., op. cit., p. 311, on these "jeroglíficos del Tiempo, y de la Muerte", representing "un cadáver corrompido, y medio comido de gusanos, que causa horror, y espanto el mirarlo; pues está tan natural, que muchos al verle, inadvertidamente, o se retiran temerosos, o se tapan el olfato, temiendo ser contaminados del mal olor de la corrupción".

38 Two examples from the historiography of the twentieth century suffice to illustrate this. For GUERRERO LOVILLO, José: "Murillo y Assereto", Archivo Español de Arte, 90, 1950, pp. 133-44, esp. p. 134, their works in the Caridad demonstrate how "Murillo -signo de su carácter- opone aquí al pesimismo de Valdés su sonriente y feliz optimismo". For DU GUÉ TRAPIER, Elizabeth: Valdés Leal, Spanish Baroque Painter. New York, 1960, pp. 1-2, "Temperamentally, he [Murillo] and Valdés Leal were directly opposed; Murillo endeavored to please, Valdés Leal to shock the spectator. Murillo was cheerfully sentimental, Valdés Leal inclined to melancholy to the verge of morbidity [...] Like Saint Ignatius of Loyola, whom he depicted many times, he was a fighter for the Faith; like all baroque painters he was fanatically concerned with the transience of life, the certain coming of death and decay. Murillo, on the other hand portrayed life's pleasures, especially in the Andalucía of his day, and the joys of radiant heaven which lay in store for the faithful. When both men were commissioned to paint canvases for the Hospital de la Santa Caridad, Sevilla, the difference in their concepts of life was clearly revealed".

${ }^{39}$ GARCÍA FELGUERA, María de los Santos: La fortuna de Murillo (1682-1900). Sevilla, 2017, pp. 152-157 on these formulaic qualities in biographies of Murillo. 
artistic environment ${ }^{40}$. In this way, the artist created a unique artistic identity perhaps performing the role of the pintor extravagante in emulation of El Greco or Tintoretto- in order to distinguish himself from Murillo, his greatest rival in Seville $^{41}$. This would have meant that they could divide the art market between them, rather than directly competing.

Ceán Bermúdez appears to have been the first biographer to criticize Valdés Leal's style for being careless and mannered, and this, of course, at the height of neo-classicism. In a frank assessment, he compares Valdés Leal with other Spanish masters who made the same "mistakes": "Pocos pintores españoles ha habido tan parecidos como D. Francisco Rizi y D. Juan de Valdés: ámbos cuidaban más de pintar mucho que pintar bien, siendo capaces de pintar mejor. Poco escrupulosos en corregir sus defectos, violentaban las figuras con actitudes forzadas. Valdes empeñado en representar mucho con pocos y repentinos golpes, miraba con desprecio á los que iban por el camino opuesto. [...] Fué aquel tan abreviado en su modo de pintar como fray Juan Rizi el benedictino y Rabiella el de Zaragoza; y si alguna vez quería detenerse en sus obras, caía en el defecto de amanerado, como se ve en algunos lienzos que hay en Sevilla"42. However, he concludes his biography with an admiration for Valdés Leal's command of the three parts of painting: "No obstante no ha habido desde su muerte otro pintor en aquella ciudad que le haya igualado en la fecundidad de invención, en el dibuxo, ni en el buen gusto del colorido" ${ }^{43}$. In this respect, he followed Palomino

${ }^{40}$ See KRIS, Ernst and KURZ, Otto: Legend, Myth, and Magic..., op. cit., pp. 120124 for established categories of artistic rivalry in the historiography of art, traditionally regarded as a motor to artists' achievement. See also PORTÚS, Javier: Metapintura. Un viaje a la idea del arte en España. Madrid, 2016, 171-175.

${ }^{41}$ Tintoretto offers a parallel case of an artist who sought artistic uniqueness. As Vasari had it in the 1568 edition of his Lives (which painters in Seville doubtless knew), this was demonstrated "in the manner of painting swift, resolute, fantastic and extravagant, and the most extraordinary brain that the art of painting has ever produced, as may be seen from all his works and from the fantastic compositions of his scenes, executed by him in a fashion of his own and contrary to the use of other painters". LEPSCHY, Anna Laura: Tintoretto Observed. A Documentary Survey of Critical Reactions from the $16^{\text {th }}$ to the 20 ${ }^{\text {th }}$ Century. Ravenna, 1983, pp. 21-22. Ibidem, pp. 27-28, 38 for early authors' (Giovanni Battista Armenini, De’ very precetti della pittura, 1587; Carlo Ridolfi, Vita di Tintoretto, 1642) appreciation of Tintoretto's markedly sketchy, apparently unfinished, style as taking account of viewers' distance from his paintings.

${ }^{42}$ CEÁN BERMÚDEZ, Juan Agustín: Diccionario..., op. cit., V, pp. 111-112. Ibidem, IV, pp. 203, 205-206, for his negative opinion of the painting of Rizi, who "Prefería la facilidad á la corrección...", although his works, Valdés-like, possess "tintas agradables, toques fáciles y atrevidos, actitudes violentas, y manifiestan fecundidad en la invención y composición". Palomino's assessment of Rizi's style is positive, by comparison.

${ }^{43}$ CEÁN BERMÚdEZ, Juan Agustín: Diccionario..., op. cit., V, p. 112. 
in recognizing the value of individuality in artists: "bien que no todos los genios se pueden medir con un módulo mismo, porque la suma vivacidad de algunos le hace romper los márgenes del común estilo" ${ }^{4}$. In the end, both sources cannot but admire Valdés Leal for a non-conformist approach to art, which set his own individuality at a premium and which was expressed in a radically singular style of painting.

Fecha de recepción: 30 de octubre de 2018

Fecha de aceptación: 5 de febrero de 2019

${ }^{44}$ Indeed, at the end of his biography, PALOMINO, Antonio: Vidas..., op. cit., p. 313, dwells on the artist's virtues, describing him as generous with other artists and, although himself proud, as having no time for the arrogant and vain. 


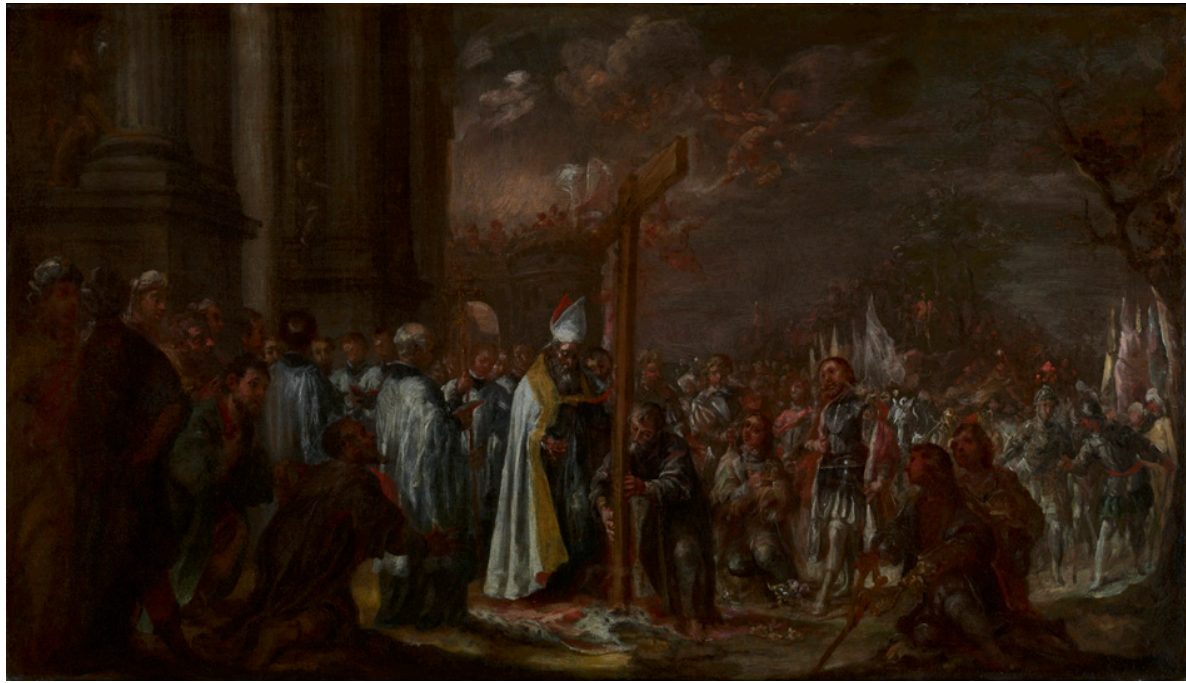

Figura 1. Juan de Valdés Leal, The Exaltation of the Cross, oil on canvas, 60 x $105 \mathrm{~cm}$, J. Paul Getty Museum, Los Angeles.

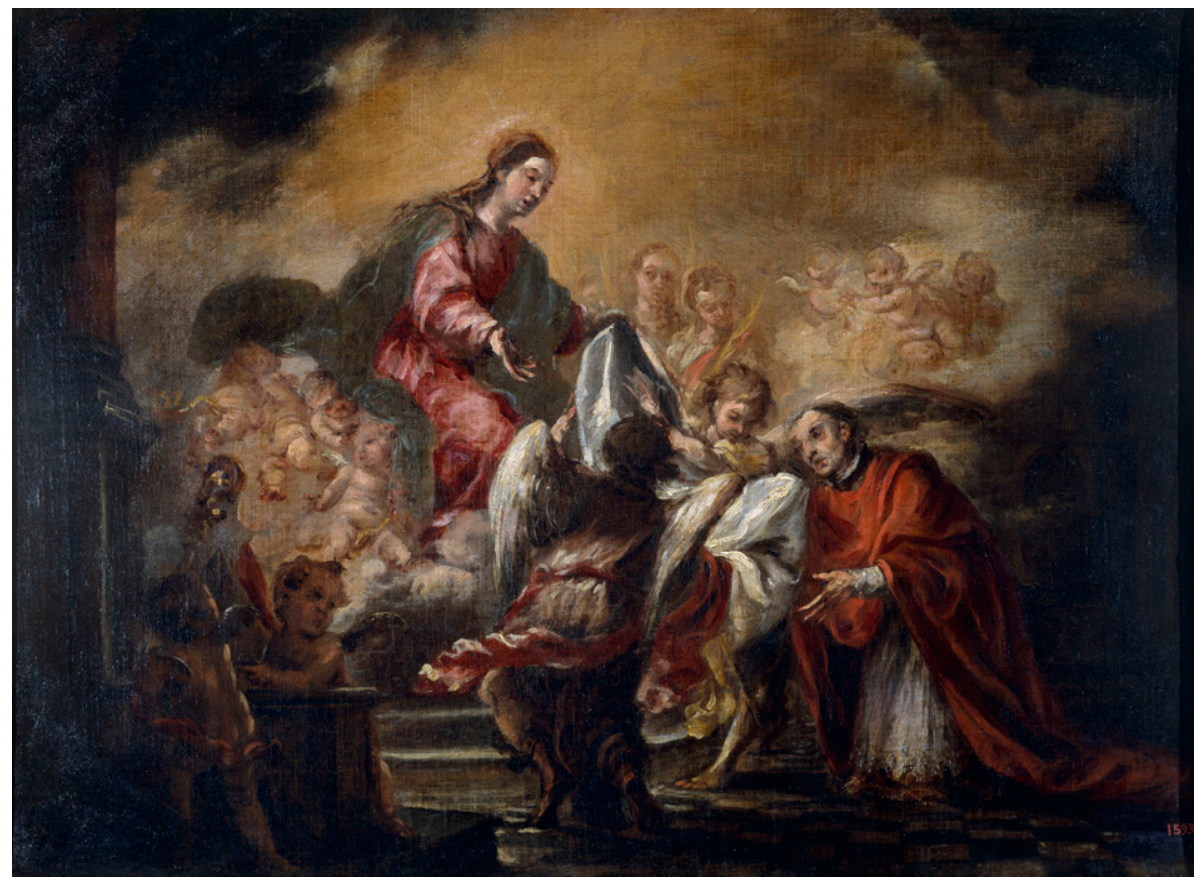

Figura 2. Juan de Valdés Leal, The Virgin Giving the Chasuble to S. Ildefonso, oil on canvas, 60,5 x $81 \mathrm{~cm}$, Museo Nacional d'Art de Catalunya, Barcelona. 